\title{
THE PLYMOUTH OFFSHORE MEDUSA FAUNA
}

\author{
By F. S. Russell, B.A., F.R.S.
}

Naturalist at the Plymouth Laboratory

(Text-figs. I-5)

\begin{tabular}{|c|c|c|c|c|c|c|c|c|c|c|}
\hline \multicolumn{11}{|c|}{ CONTENTS } \\
\hline Introduction & . & . & . & . & . & . & . & . & . & $4 \mathrm{II}$ \\
\hline The Plymouth & Medusa Fauna . & . & . & . & . & . & . & . & . & $4 \mathrm{I} 2$ \\
\hline The Ringtrawl & Catches, I930-7 & . & . & . & . & . & . & . & . & 418 \\
\hline Observations or & Certain Medusae & . & . & . & . & . & . & . & . & 420 \\
\hline Purena gem & mifera (Forbes). & . & . & . & . & . & . & . & . & 420 \\
\hline Zanclea cos & tata Gegenbaur & . & & . & . & . & . & . & . & 420 \\
\hline Bougainvill & ia britannica Forbes & . & . & . & . & . & . & . & & $42 \mathrm{I}$ \\
\hline Bougainvill & ia principis (Steenstru & & . & . & . & . & . & . & . & 423 \\
\hline Turritopsis & nutricula McCrady & . & . & . & . & . & . & . & . & 423 \\
\hline Amphinema & rugosum Mayer & . & . & . & . & . & . & . & . & 423 \\
\hline Pochella po & lynema Hartlaub & . & & . & . & . & , & . & . & 425 \\
\hline Laodicea ur & ndulata (Forbes \& Go & odsir) & & . & . & . & . & . & . & 427 \\
\hline Cosmetira 1 & bilosella Forbes . & . & . & . & . & . & . & . & . & 428 \\
\hline Tiaropsis $m$ & uulticirrata (M. Sars) & . & . & . & . & . & . & . & . & 429 \\
\hline Phialidium & hemisphericum (L.) & . & . & . & . & . & . & . & . & 429 \\
\hline Eucheilota & clausa (Hincks). & . & . & . & . & . & . & . & . & 432 \\
\hline Helgicirrha & schulzei Hartlaub & . & . & . & . & . & . & . & . & 432 \\
\hline Aglantha $r$ & osea (Forbes) & . & . & . & . & . & . & . & . & 433 \\
\hline Summary . & . & . & . & . & . & . & . & . & . & . 435 \\
\hline References & . & . & . & . & . & . & . & . & . & $43^{8}$ \\
\hline
\end{tabular}

\section{INTRODUCTION}

A system of regular weekly collecting with the $2 \mathrm{~m}$. stramin ringtrawl was started in 1930 with the object of comparing fluctuations in the composition of the plankton over a number of years, in the hope that certain animals might thus be found which could be used as "an index of conditions that may lead to other fluctuations such as those of the fisheries" (Russell, 1933). A direct outcome of this work has been the recognition of a number of animals that can be used as indicators of water masses and the correlation of variations in their occurrence with the numbers of young fish in the plankton. In the preliminary paper quoted above it was noted that such changes as occurred in the composition of the plankton from year to year were especially noticeable in the medusa population. Medusae have been regarded by some workers (e.g. Kramp, I927) as very valuable indicators, liberated at certain times from their hydroids in fixed localities and drifting in the water masses for periods that can be estimated with a correct knowledge of their life histories. Since the inception of this work in 1930 close attention has been paid to certain medusae 
which appeared to be spasmodic in their occurrence. But it was soon noticed that the differences between some years were so marked that it was advisable to distinguish all medusae occurring in the catches. The collections have also been supplemented since 1933 by almost daily examination of living plankton catches over long periods.

These observations have now been made for 8 years, with the result that it is now possible to obtain a fair view of the medusa fauna in offshore waters off Plymouth and its changes from season to season and year to year.

\section{The Pi.ymouth Medusa Fauna}

The "Plymouth Marine Fauna" (I93I) records forty-one species of planktonic Hydromedusae, twenty-three Anthomedusae, fifteen Leptomedusae, two Trachymedusae and one Narcomedusa; four species of Siphonophora; and five species of planktonic Scyphomedusae. During the 8 years' observations since 1930 nine more species have been added to the fauna, viz.:

Anthomedusae: Turritopsis nutricula McCrady, Pochella polynema Hartlaub.

Leptomedusae: Eucheilota clausa (Hincks), Helgicirrha schulzei Hartlaub, Aequorea vitrina Gosse.

Trachymedusa: Gossea corynetes (Gosse).

Siphonophora: Muggiaea kochi (Will).

Scyphomedusae: Pelagia noctiluca Péron \& Lesueur, Discomedusa lobata Claus.

Since I930 I have myself taken all the species recorded at Plymouth except Eucodonium brownei, Mitrocomella fulva, Solmaris corona, and Cyanea capillata. (The specific names used in this report are those of the Plymouth Marine Fauna, except for Zanclea and Eirene.) The Siphonophora and Scyphomedusae are not referred to here except in the lists on pp. 416 and 4I7.

During the course of these 8 years' observations many data have accumulated on the occurrence of medusae in the different months of the year. By combining these results with the records given in the Plymouth Marine Fauna it has been possible to produce in Table I a reliable guide showing in which months of the year any species of medusa may be expected to occur and in which month any species has been recorded as being abundant. In this table the species have been arranged approximately in the order of their geographical distribution from north to south, and it can be seen at a glance that the more northerly species are usually present in the plankton earlier in the year than the more southerly. Table I thus gives a picture of the seasonal progression of the composition of the medusa fauna off Plymouth. The seasonal sequence according to geographical distribution is to be expected on account of the seasonal range of the temperature of the sea off Plymouth, and in this respect it is in agreement with the results already published for the young fish (Russell, 1930-7, Vol. xx, p. 147). But the information given in 
Table I does not necessarily mean that all the species mentioned are certain to be found in any year. It must be supplemented by a close examination of the distribution of the species both geographically and with respect to the movements of the water masses in the English Channel. But as our knowledge

\section{Table I. Seasonal Distribution of Plymouth Medusae}

$\times$ recorded as present; $\mathbf{x}$ months of greatest abundance; N.B., northern boreal; B., boreal; S.B., southern boreal; S., southerly; C., cosmopolitan.

ANTHOMEDUSAE

Rathkea octopunctata

Hybocodon prolifer

Euphysa aurata

Steenstrupia nutans

Podocoryne areolat

Podocoryne carnea

Bougainvillia principis

Sarsia tubulosa

Sarsia eximia

Bougainvillia britannica

Ectopleura dumortier:

Willia stellata

Lizzia blondina

Leuckartiara octona

Bougainvillia ramosa

Purena gemmifera

Amphinema rugosum

Zanclea costata

Sarsia prolifera $\neq$

Dipurena halterata

Purena strangulata

Amphinema dinema

Turritopsis nutricula

Eucodonium browne

Pochella polynema

LEPTOMEDUSAE:

Tiaropsis multicirrata

Phialidium hemisphericum

Obelia spp.

Phialella cymbaloides

Cosmetira pilosella

Mitrocomella brownei

Mitrocomella fulva

Saphenia gracilis

Eutima insignis

Aequorea forskalea

Aequorea vitrina

Laodicea undulata

Eucheilota clausa

Helgicirrha schulzei

Eirene viridula

Octorchis gegenbaur

Agastra mira

TRACHYMEDUSAE:

Aglantha rosea

Liriope exigua

Gossea corynetes

NARCOMEDUSA :

Solmaris corona
Jan. Feb. Mar. Apr. May June July Aug. Sept. Oct. Nov. Dec.

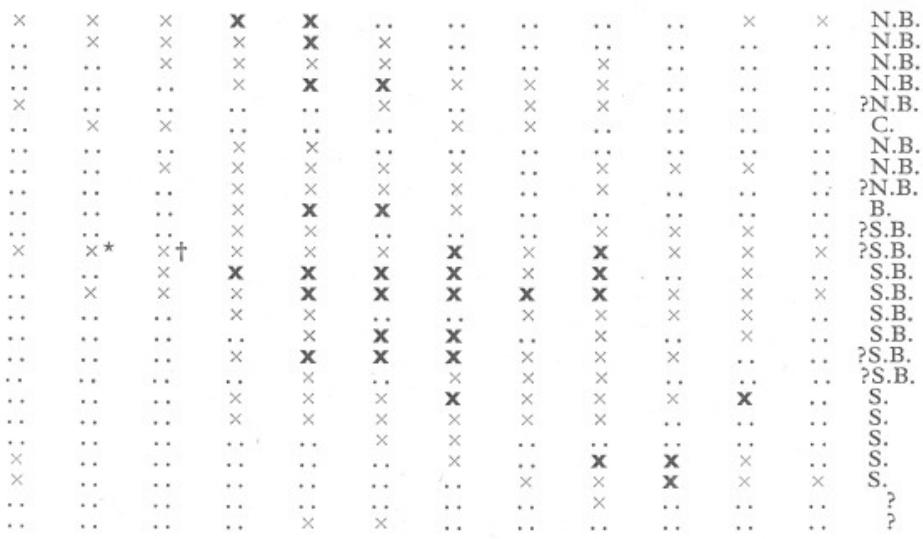

* Hydroid with medusa ready for liberation. (E. T. Browne, MS. notes, February 22 I899.)

$\uparrow$ Liberated from hydroid, March $30 \mathrm{I} 936$.

$\ddagger$ Plymouth Marine Fauna gives Jan.-Oct.; this is possibly a misprint for Jun.-Oct.

February 21 1938 one specimen.

of the plankton content of the different types of water grows we are becoming better able to say which are the species that are most likely to occur off Plymouth during any' month in which specimens are required.

The late $\mathrm{MrE}$. T. Browne laid a very sound foundation for a comparison of the different areas of distribution on the south and western shores of the British 
Isles by his careful and prolonged studies, especially at Plymouth, Valencia, Port Erin and Millport. In a comparison of the faunas of Plymouth and Valencia, Browne (1900) gave the following species as occurring at Valencia but not at Plymouth: Bougainvillia pyramidata, Dipleurosoma typicum ${ }^{\star}$, Melicertum octocostatum, Laodicea undulata, ?Aequorea forskalea, Aglantha rosea and Gossea corynetes. Of these only Bougainvillia pyramidata, Dipleurosoma typicum and Melicertum octocostatum now remain not recorded from Plymouth, but to the list of those found only at Valencia must be added Leuckartiara nobilis and L. breviconis (see Hartlaub, I9II). The only species recorded from Plymouth and not from Valencia are Turritopsis nutricula, Pochella polynema, Eucheilota clausa and Helgicirrha schulzei; of these the last three have been described as new species since Browne's observations were made and Eucheilota clausa has now been found at Valencia (see p. 432). Browne's observations at Valencia were further supplemented by the Misses Delap (1905, 1906).

Browne (1906) also made a comparison between the medusae recorded from the English Channel and those taken in the Bay of Biscay on the cruise of H.M.S. Research. Of those species living within Ioo fathoms of the surface in the Bay Aglaura hemistoma and Rhopalonema coeruleum had not been recorded in the Channel and they still remain unrecorded from Plymouth.

But such faunistic comparison is not sufficient in itself; to it must be added a knowledge of the comparative abundance of the species in the different localities. Unfortunately, I cannot give numerical data for many of the smaller species, but data for all those species occurring in the stramin ringtrawl catches will be found in Tables II and III. From the examination of townet catches and of the previously published records a good idea can, however, be obtained as to which species are common and which scarce. But while one species may be common in one year it may be very scarce the next. A comparison of the Plymouth medusa fauna with that of other regions, coupled with a knowledge of the occurrence of the hydroids of some species and a critical analysis of the data in Table III, enables us now to explain to some degree these changes in the composition of the fauna from year to year. There are some species which can undoubtedly be regarded as visitors to the area, but owing to Plymouth's geographical position it is difficult to decide for all species which are visitors and which may be called truly indigenous. This circumstance is brought about by the complicated hydrographic conditions existing in the Channel area, and in order to understand the composition of the medusa fauna off Plymouth we must have some idea of these conditions.

Through oceanic circulation and wind effects there is a resultant flow of water through the straits of Dover into the southern North Sea. The supply from which this water is ultimately drawn enters the western mouth of the

* This species was recorded off Brighton in 1879 by Haeckel in his System der Medusen, p. 636 . 
Channel either from the west or the south-west. It is generally conceded that more water enters the Channel than can pass through the Dover straits, and this surplus probably drifts north-west or north past the Scillies-Land's End region, though the actual state of affairs here is still not clear (Carruthers, I934). To the west of the mouth of the Channel is an anticyclonic swirl lying over the shallow continental plateau south of Ireland. This swirl varies in its extent and position; at times it appears to block the mouth of the Channel and at others it apparently retreats farther north, thus laying the Channel mouth open to more oceanic water from the south and south-west. When there is a strong flow through the Dover straits, water may move up Channel past Plymouth either from the swirl or from the ocean according to the conditions existing off the Channel mouth. In the Channel itself there must be a body of water constantly being added to from the west and dissipated to the east, or hemmed into the coast to allow for passage of more oceanic water. The circulation of water in the Channel itself is clearly very variable from time to time.

It has been shown (Russell, I936 a) that the various water types carry their own faunistic associations of plankton or indicators and, of these, three types have so far been elucidated:

(I) "Channel" water, characterized by Sagitta setosa and a poverty of plankton.

(2) "Elegans" (swirl) water, characterized by S. elegans and a number of associated species and a rich plankton.

(3) "Oceanic" water, characterized by salps and doliolids and their associated fauna.

There have also been during the past 3 years indications of the possible existence of a fourth type in which there are always large numbers of pilchard eggs and few Sagitta of either species; but its relationship in the general scheme is not yet clear.

These different types have also different species of medusae associated with them, and it is this fact that makes the true character of the Plymouth medusa fauna difficult to decide. The "elegans" water for instance contains in the summer great numbers of Cosmetira and Laodicea. In years in which this water is drifted past Plymouth it is natural to suppose that a stock of their hydroids should be produced on the sea bottom off Plymouth. Thus if a period of several years of absence of "elegans" water off Plymouth follows there is at first a good stock of hydroids to liberate medusae, but the numbers of adult medusae thereafter decrease. Presumably there is either an insufficient food supply or the type of water is for some reason harmful and not many medusae grow to maturity. The stock of hydroids will thus gradually diminish, but it is unlikely that for common species sufficient time ever elapses off Plymouth to allow the stock to die out before there is an importation of large numbers of fresh medusae from the west.

Similarly Turritopsis appears to be a species characteristic of "Channel" 
water, associated with Sagitta setosa. In periods when Channel water predominates off Plymouth it is thus possible that a local population of Turritopsis hydroids may arise. But Turritopsis is never very abundant, so that it is probable that its hydroid may die out at Plymouth after a prolonged continuation of "elegans" conditions.

This colonization of the grounds by hydroids from drifting medusae must be constantly borne in mind, and it can be understood that it is difficult to decide which species can be regarded as permanently indigenous to the waters off Plymouth. Even such medusae as Phialidium and Obelia, which are always present, become much more abundant during periods of predominance of "elegans" water presumably on account of the increased supply of food.

With these difficulties in mind I have attempted to draw up the following preliminary list of Plymouth medusae divided into indigenous and visiting species and indicating whether they are common or scarce. It is likely that in time, as our knowledge of their distribution increases, more of those species here listed as indigenous will be shown to be visitors.

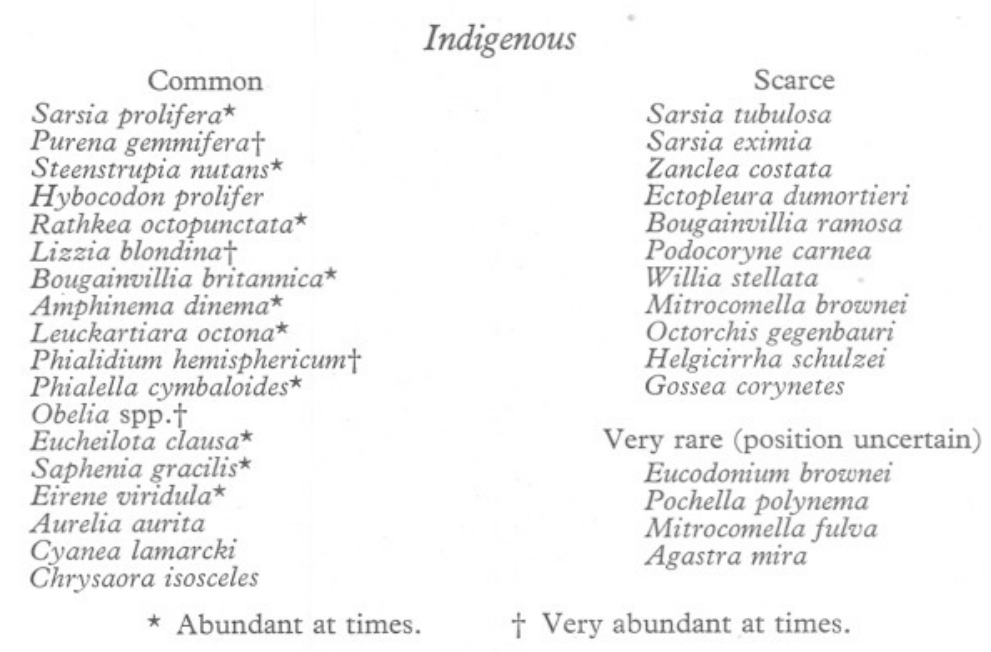

Visitors

Abundant at times Amphinema rugosum Laodicea undulata Cosmetira pilosella Aglantha rosea Liriope exigua Muggiaea atlantica Muggiaea kochi

Common at times Turritopsis nutricula

\author{
Scarce \\ Dipurena halterata \\ Purena strangulata \\ Euphysa aurata \\ Bougainvillia principis \\ Podocoryne areolata \\ Tiaropsis multicirrata \\ Aequorea forskalea \\ Aequorea vitrina \\ Solmaris corona \\ Pelagia noctiluca \\ Discomedusa lobata
}


The above visitors can probably be divided among the three types of water as follows:

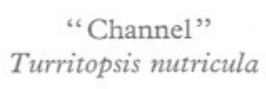

\author{
"Elegans" \\ Dipurena halterata \\ Purena strangulata \\ Euphysa aurata \\ Bougainvillia principis \\ Podocoryne areolata \\ Amphinema rugosum \\ Laodicea undulata \\ Cosmetira pilosella \\ Tiaropsis multicirrata \\ Aequorea spp. \\ Aglantha rosea
}

\author{
"Oceanic" \\ Aglantha rosea \\ Liriope exigua \\ Solmaris corona \\ Muggiaea atlantica \\ Muggiaea kochi \\ Pelagia noctiluca \\ Discomedusa lobata
}

The above lists require one or two words of comment. The reservation must be made that at any time occasional specimens of visiting species may be found, but their presence in larger numbers is a sure indication of water movement.

As regards the indigenous medusae this list needs the qualification that in some years, owing to certain hydrographical conditions (see p. 4I9), all species may appear to be scarce. As regards the relative abundance of the different species it should however still hold good.

The scarcity of Sarsia tubulosa and S. eximia in offshore waters is probably due to the very littoral or estuarine distribution of their hydroids. These are quite common inshore. It is also rather remarkable that while the hydroids of Zanclea costata, Bougainvillia ramosa, and Podocoryne carnea are common off Plymouth the medusae themselves seem to be rather scarce. It may possibly be accounted for by the fact that the medusae, especially those of $P$. carnea, may often mature at a very undeveloped stage, thus only being present in the plankton for a very short time.

It is also to be noted that in the above list Aglantha rosea has been included as an indicator both of "elegans" and of "oceanic" waters. Aglantha is essentially an oceanic medusa, nevertheless a large stock appears to flourish in the water south of Ireland. It may thus possibly be drawn from two sources, though results seem to show that it is more usually associated with "elegans" conditions.

Euphysa aurata and Bougainvillia principis have never been recorded commonly off Plymouth, yet they are common south of Ireland. The reason for their continuous scarcity at Plymouth is not clear.

The occurrence of the oceanic indicators is not yet fully elucidated. For instance, Liriope has so far only appeared abundantly off Plymouth during periods of essential "elegans" predominance (see p. 423).

Before passing on to the details of the ringtrawl catches mention should be made of an interesting feature of the Plymouth medusa fauna as a whole. This is that of the northern species by far the majority are Anthomedusae. This fact led me to make a casual survey of the medusae of cold waters (see 
e.g. Thiel, I932; Browne, I902, I9I0). It is evident that of the medusae liberated from hydroids the majority in cold waters are Anthomedusae or so-called "primitive" Leptomedusae such as laodiceids and mitrocomids. This difference between the medusa faunas of cold and warm waters seems worthy of a closer investigation. In this respect it is interesting to note that all the laodiceids and mitrocomids whose hydroids are so far known have "Cuspidella" hydroids. It may well be that this is the primitive type from which many of the campanulate hydroids have evolved and that the evolution of the Leptomedusae has taken place mainly in warm waters. Being of more recent evolution than the Anthomedusae they have not yet given rise to many cold-water species.

\section{The Ringtrawl Catches, I930-7}

The average catches for each month in the years 1930-7 are given in Table III, p. 436. These are based on half-hour oblique hauls taken usually each week at a position 2 miles east of the Eddystone (for the actual dates of hauls see Russell, 1930-8). The sums of the average monthly catches of each year are given in Table II.

Before discussing the results of these collections a few remarks must be made on the identification of species. As already mentioned, owing to the size of the mesh employed only the larger species are represented in these catches. Such species as Purena gemmifera, Rathkea octopunctata and Lizzia blondina, the majority of which are not retained by the net, have not been counted, although when they are very abundant in the plankton a few may be found in the catches. Owing at times to the large masses of other plankton animals in the catches the medusae are often in a very bad state of preservation, and when numerous themselves could not be subjected to so close a critical examination as is to be desired. Long experience of dealing with such catches in bulk has, however, enabled me to be fairly certain that the identifications are correct, and the re-examination at a later date of previously sorted material, and frequent observations of living samples taken at the same times as the catches which were preserved, have convinced me that a reliable picture has been produced of the medusa fauna taken by the ringtrawl. There are, however, one or two species that can only be separated for certain by a critical examination under the microscope. These are Mitrocomella brownei, Eucheilota clausa and Phialella cymbaloides, which in bulk catches sorted with the naked eye may easily be mistaken for Phialidium hemisphericum. No regular attempt was made to discriminate between these species and all have been counted under Phialidium. As Phialidium is by far the most abundant the inclusion of the other species has probably not produced a very false impression. Of the other species Phialella cymbaloides and Eucheilota clausa are quite common at times, but Mitrocomella brownei is scarce. Saphenia gracilis and Eutima insignis have also been counted together as Saphenia. They are often 
in too bad a state to be sure of the number of tentacles as the manubria become twisted together, and it is indeed uncertain whether they are distinct species.

When we examine the results as a whole (see Table II) the most striking feature is the great decrease in the numbers of total medusae in the years I935, I936 and I937 as compared with the previous years. The high numbers in the years I930, I93I and I932 are in part made up by the abundance of Laodicea, Cosmetira, Aglantha and Liriope, which were visitors to the area

\section{Table II. Sums of Average Monthly Catches of Medusae in the Ringtrawl for Each Year at Plymouth}

\begin{tabular}{|c|c|c|c|c|c|c|c|c|}
\hline & I930 & I93I & I932 & I933 & I934 & I935 & I936 & I937 \\
\hline Steenstrupia nutans & 46 & I23 & 64 & I8 & 1,232 & 6 & I5 & 59 \\
\hline Bougainvillia britannica & 296 & II 2 & 402 & 4 & 1,285 & 33 & 2 & 2 \\
\hline Turritopsis nutricula & $\ldots$ & . & .. & 17 & I & 3 & 25 & 34 \\
\hline Amphinema dinema & . & . & 6 & 8 & 7 & 107 & 55 & 70 \\
\hline Amphinema rugosum & 473 & I & $2 \mathrm{I}$ & I3 & 2 & .. & 7 & 2 \\
\hline Leuckartiara octona & 658 & 513 & 403 & 218 & I08 & 102 & 68 & I6 \\
\hline Laodicea undulata & $5, \mathrm{I} 4 \mathrm{I}$ & 2,527 & 22 & 70 & 282 & 208 & 4 & I8 \\
\hline Cosmetira pilosella & $89 \mathrm{I}$ & 2, III & 2,599 & 326 & 342 & $4 \mathrm{I}$ & 6 & 7 \\
\hline Obelia spp. & I 5,4 I 8 & I, 3II & I 8,656 & 2,730 & I3,649 & 1,935 & 797 & $2,15 I$ \\
\hline Phialidium hemisphericum & 8,950 & I2,554 & 5,862 & 9,512 & 5,179 & 600 & 948 & 2,605 \\
\hline Saphenia gracilis & I57 & 22 & 28 & 67 & 34 & 39 & 136 & 108 \\
\hline Octorchis gegenbauri & . & 28 & + & 8 & IO & 36 & I4 & 25 \\
\hline Eirene viridula & . & I,3 I 4 & 83 & 56 & I & 7 & 2 & 39 \\
\hline Helgicirrha schulzei & & & & & & 3 & 2 & 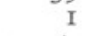 \\
\hline Aequorea forskalea & + & I3 & 4 & . & + & I & 2 & + \\
\hline Gossea corynetes & & I2 & I & 4 & I I & 6 & I & I3 \\
\hline Aglantha rosea & 38,439 & I43 & . & I & 32 & 22 & 425 & 60 \\
\hline Liriope exigua & I 5,522 & 327 & . & 3 & - & + & . & . \\
\hline Total medusae & $85,99 \mathrm{I}$ & $2 \mathrm{I}, \mathrm{III}$ & $28, \mathrm{I} 5 \mathrm{I}$ & 13,055 & 22,175 & 3,149 & 2,509 & $5,2 \mathrm{IO}$ \\
\hline $\begin{array}{l}\text { Total young fish (less } \\
\text { clupeids) }\end{array}$ & $\mathrm{I}, 5 \mathrm{I} 7$ & $\mathrm{I}, 625$ & $\mathrm{I}, 556$ & I, 337 & I, I 44 & 430 & 487 & 557 \\
\hline
\end{tabular}

associated with the predominance of "elegans" and "oceanic" water. But when we regard the commonest truly indigenous species, such as Leuckartiara, Phialidium and Obelia, we notice that in the later years there has on the whole been a great decrease in numbers. The decrease in the numbers of young fish in the plankton during this period has already been noted (Russell, I $936 \mathrm{a}$ ), and there can be little doubt that the decrease in numbers of medusae is an associated phenomenon. At the foot of Table II are included the corresponding numbers for all young fish (less clupeids) taken in the same series of collections. The low numbers of young fish in the years I935, I936 and 1937 closely parallel those for the medusae. The abundance of young fish has been shown to follow closely the winter maximum of phosphorus content of the water (Russell, I936 a), and it seems quite evident that this lack of nutrient matter has resulted in a decreased supply of planktonic food for such predatory organisms as fish and medusae and affected their survival rate. 
If we examine the list in Table II in greater detail other points of interest are to be found. In the year 1934 Steenstrupia nutans and Bougainvillia britannica were both unusually abundant; in that year there were more Sagitta elegans present in May than in recent years. The sudden appearance of Turritopsis in 1933 and its persistence thereafter is to be associated with the prevalence of Channel water. There has been a sudden increase in abundance of Amphinema dinema in I935, I936 and I937, while A. rugosum was very abundant in 1930 during the year of greatest "elegans" predominance. The year I93I was outstanding for the numbers of Eirene viridula; it is to be noted that this abundance coincided with the presence of Salpa mucronata and Doliolum gegenbauri which occurred only in that year. No attempt can be made to explain all these differences from year to year, but they are here noted for comparison with future years.

\section{Observations on Certain Medusae}

In the following pages are given further details on the biology of some of the Plymouth medusae together with a few observations of note on structural details.

Purena gemmifera (Forbes).

I have noticed that the tentacles of living medusae of Purena gemmifera show a characteristic vibrational movement. This movement is produced by cilia on the tentacles. These cilia which appear to be confined to the nematocysts clusters and terminal knob can already be seen on the tentacles while the young medusae are still attached to the stomach of the parent. A careful examination of living specimens of other medusae has so far shown no similar ciliation in other Sarsiid species.

\section{Zanclea costata Gegenbaur.}

In a previous publication (Russell \& Rees, I936) Zanclea gemmosa McCrady with two tentacles was provisionally kept distinct from Zanclea costata Gegenbaur until it could be shown either that the latter was liberated from the hydroid with four tentacles, or that a medusa with four tentacles could develop from one with two. In 1937 I obtained a complete series of Zanclea medusae from the plankton showing the development of a two-tentacled medusa into one with four tentacles. Among these specimens a medusa $\mathrm{I} .5 \mathrm{~mm}$. in height had two opposite perradial tentacles, another $2 \mathrm{~mm}$. in height had two fully grown opposite perradial tentacles, and on the other two perradial bulbs there were very short tentacles just developing. Another 3. I mm. in height had four tentacles of nearly equal size. There seems therefore to be little doubt that the medusae with two and those with four tentacles are the same species and referable to Zanclea costata Gegenbaur.

It is hoped to deal with the questions raised by Weill (1936) and Ranson (1937) about the nematocyst armature on the umbrella in a future publication. 
Bougainvillia britannica Forbes.

The year I934 was outstanding for the abundance of this species and the presence of such large numbers furnished an opportunity to study the growth and development of the medusa in the plankton. Measurements of height and width were made on a large number of preserved specimens from the plankton on April 20 and May 3, I6 and 24. The actual period when the medusae were present in the plankton and their numbers in the weekly catches were as follows:

\begin{tabular}{|c|c|c|c|}
\hline April & I0 & May 2 & I 567 \\
\hline , & 4 & $\Rightarrow 9$ & $4 \mathrm{I}$ \\
\hline " & 4 & $\Rightarrow 16$ & $273 \mathrm{I}$ \\
\hline " & 233 & " 24 & $\begin{array}{r}\text { I528 } \\
244\end{array}$ \\
\hline
\end{tabular}

When alive the medusa is usually somewhat higher than it is wide; when preserved, however, contraction causes them often to be as wide as they are high. In order to range the medusae after measurement the height of each

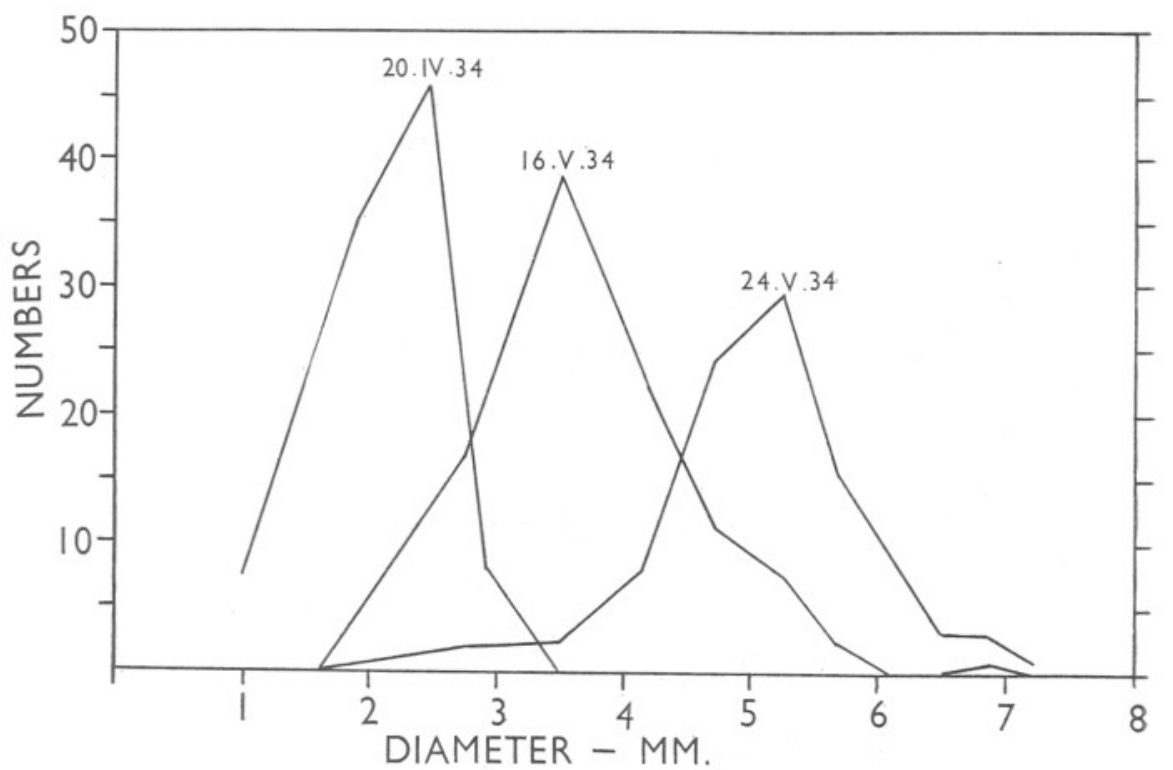

Fig. I. Growth of Bougainvillia britannica from samples collected in the plankton off Plymouth, 1934. The curves show the numbers of specimens of different diameters on April 20, May 16 and 24.

specimen was multiplied by its width and the square root of the product taken. Thus the measurements of the medusa diameter given in the table on p. 422 and Fig. I are for spherical medusae and would probably have been very slightly greater if the measurements of height had been made on living material. The data have been supplemented by some material collected on April 20 when the ringtrawl was not used. 
Growth. The results of measurements made on April 20, May I6 and 24 are shown in Fig. I. The growth of the medusae is well illustrated, the mode increasing successively from 2.5 to 3.5 and $5.25 \mathrm{~mm}$. on each successive date. The maximum size attained is about $7 \mathrm{~mm}$. The medusa had disappeared from the plankton completely by June 6 . Thus the period from the date of first appearance (April 6) was 2 months. By May I6 some of the gonads were mature and planulae were reared. The dates of appearance of the medusa in the plankton coupled with the gradual increase in size shown in Fig. I afford fair evidence that the length of life of the medusa Bougainvillia britannica in Plymouth waters is not more than 2 months. Kramp (1927) has said that in Danish waters "it lives presumably for about 2 months, but we know nothing certain as to this".

Development. The medusa when first liberated from its hydroid has four single marginal tentacles and four unbranched oral tentacles. As growth proceeds the number of marginal tentacles increases on each of the four tentacular bulbs and the oral tentacles branch dichotomously. Observations were made on a large number (I40) of medusae of different sizes and the sequence of their development found. The examination gave the following results:

Diameter (mm.)
$\mathrm{I} \cdot 5$
$\mathrm{I} \cdot 75$
$2 \cdot 0$
$2 \cdot 25$
$2 \cdot 5$
$2 \cdot 75$
$3 \cdot 0$
$3 \cdot 25$
$3 \cdot 5$
$4 \cdot 0$
$4 \cdot 5$
$5 \cdot 0$
$6 \cdot 0$
$7 \cdot 0$
$7 \cdot 5$

Number of tentacles on
each marginal bulb
3
$3-4$
$4-5$
$4-5$
$4-6$
$5-6$
$5-7$
$5-9$
$8-9$
$9-$ II
IO-II
IO-I2
I I-I3
I4-I5
16-I7

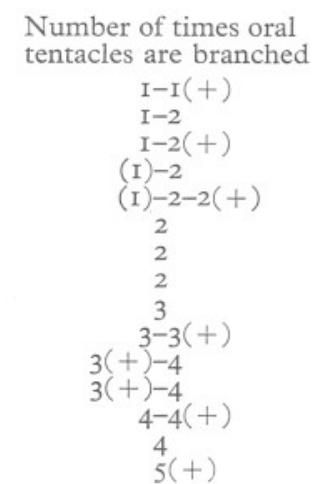

Note. $(+)$ implies that some of the branches are just starting to subdivide. Numbers in brackets are exceptional occurrences.

It is evident from this table that full-grown medusae will have about eleven to seventeen tentacles on each marginal bulb, and the oral tentacles will be dichotomously branched four or five times. This agrees with observations by Hartlaub (I9II) on a swarm in the North Sea. His specimens had well-developed gonads and averaged 5-7 $\mathrm{mm}$. in height, and the number of tentacles on each marginal bulb averaged twelve to sixteen. Hartlaub gives I $2 \mathrm{~mm}$. in height as the largest size, the tentacles on each marginal bulb up to 30 in number, and oral tentacles branching at most seven times. Such individuals must be exceptional. 


\section{Bougainvillia principis (Steenstrup).}

This species appears to be very rare at Plymouth. One specimen was taken in May 1935, one* in May I936 and one in April I937. The only previous record is the end of April I893 (Garstang, I894). In its distribution it is much more northerly than $B$. britannica, although it occurs more commonly at Valencia than at Plymouth.

\section{Turritopsis nutricula McCrady.}

This species has not been recorded in the Plymouth fauna prior to this series of observations. It was first seen in I933, and has occurred each year since. The species is indigenous in the southern North Sea and eastern end of the English Channel, where it has been used by Kramp (I930), Wulff, Bückmann, and Künne (1934) and Künne (1937) as an indicator of water movements. Its first appearance here and its continuation is coincident with the decrease in "elegans" water which has been so noticeable after the year I932. Browne (I898) did not find the species at Plymouth in the years I893, I895 and I897 although working in September, a month in which Turritopsis occurs in the plankton. Browne's records show that those years were characterized by the presence of Liriope; this would explain the absence of Turritopsis at that time, since Liriope has only appeared in numbers during the last eight years in I930-I when "elegans" conditions were most predominant. Künne (I934) states that Turritopsis penetrated farther into the southern North Sea in I932 than in I933, in which year it appeared off Plymouth.

There has in the past been some discussion as to the identity of the European species of Turritopsis, which was described under the specific name polycirrha. Although Mayer (I9I0) could detect no specific differences between polycirrha and the American nutricula, Hartlaub (I9I I) kept them distinct. He maintained that in polycirrha the endodermal mass was not in four sections, and that the radial canals did not penetrate the endodermal mass or widen into chambers as figured by Brooks. Later (I9I7) he recorded a specimen from Heligoland that agreed with Brooks' figure as regards the widening of the radial canal, though he maintained that the identity of the two species still remained unproved. Their identity has, however, been accepted by Mayer (I9I0), Bigelow (I9I3) and Kramp (1930); it is accepted here on the grounds that all specimens seen at Plymouth showed the endodermal mass divided into four sections which were traversed by the radial canals. Cavities were also frequently seen in the endodermal mass, which when radially disposed could give rise to the appearance figured by Brooks.

Amphinema rugosum Mayer.

In earlier literature there has been considerable confusion between this species and $A$. dinema (see Rees and Russell, I937). Since I was myself at

* I am indebted to Dr P. L. Kramp for confirmation of the identification of this specimen. 
first confused by Hartlaub's (I9II) description of one species under the name of the other I have found it necessary to re-examine all the previous samples on which any data have been published; as I expected to find, all species under the specific name dinema should have been rugosum (a revision of my data will be found in the footnote $)$.

From the occurrence of $A$. rugosum in such numbers in 1930 it appears probable that the species is associated with "elegans" conditions. The true distribution of the species is not yet known, but in 1933 while cruising in Col. E. T. Peel's yacht St George I took a plankton sample on July 9 at a position north of the Fair Isle Channel $\left(59^{\circ} 42^{\prime} \mathrm{N} . ; 2^{\circ}\right.$ I0' W.). This was a typical elegans association and there were a number of $A$. rugosum present. The species is therefore not likely to be normally indigenous to Plymouth, and it is perhaps significant in this respect that the only two records of its hydroid off Plymouth are on floating objects that may have drifted into the area (see Rees and Russell, 1937).

A detailed examination was made of a number of specimens taken off Plymouth in June and July 1930. The numbers of marginal tentaculae were counted on sixty-three specimens with the following results:

\begin{tabular}{|c|c|c|c|}
\hline $\begin{array}{l}\text { Total number } \\
\text { of marginal } \\
\text { tentaculae }\end{array}$ & $\begin{array}{l}\text { Number of } \\
\text { individuals }\end{array}$ & $\begin{array}{l}\text { Distribution of } \\
\text { tentaculae on } \\
\text { either side of } \\
\text { large tentacles }\end{array}$ & $\begin{array}{l}\text { Number of } \\
\text { individuals }\end{array}$ \\
\hline II & I & $5+6$ & I \\
\hline 12 & 2 & $5+7$ & I \\
\hline I3 & 6 & $5+8$ & I \\
\hline I4 & I4 & $6+6$ & I \\
\hline 15 & I0 & $6+7$ & $5 \dagger$ \\
\hline 16 & 7 & $6+8$ & I \\
\hline 17 & 8 & $7+7$ & I3 \\
\hline 18 & 4 & $7+8$ & 10 \\
\hline I9 & $\begin{array}{l}4 \\
4\end{array}$ & $7+9$ & $2 \dagger$ \\
\hline 20 & I & $8+8$ & 5 \\
\hline $2 \mathrm{I}$ & 3 & $8+9$ & 8 \\
\hline \multirow[t]{7}{*}{22} & 3 & & I \\
\hline & & $9+9$ & 4 \\
\hline & & $9+10$ & 3 \\
\hline & & $9+12$ & I \\
\hline & & $10+10$ & I \\
\hline & & $\begin{array}{l}10+I I \\
10\end{array}$ & 2 \\
\hline & & $\mathrm{II}+\mathrm{II}$ & 3 \\
\hline
\end{tabular}

From these figures it is evident that there is considerable variation in the number of tentaculae, which have been recorded up to twenty-four in number, the most frequent numbers here being fourteen to seventeen. The

* I have examined the medusae in my collections and find that in all my previously published papers the medusae recorded under the names Stomotoca dinema or Amphinema dinema were in fact $A$. rugosum. These records are in this fournal, Vol. XIII, p. 78I, July I5-I6 I924; Vol. xiv, p. 569, June I7, I9; July I, I6, 29 I925; Vol. xv, Table I, June I7, I8, I9 I925; Vol. XIX, Table I, June IO, I9, July I4, 23, 29, August I4 I930. 
number must naturally vary with the age and size of the medusa, but the preserved specimens were too contracted to measure.

An analysis of the distribution of the marginal tentaculae gives the following results:

Equal numbers on either side of two main tentacles $\begin{array}{llll} & \ldots & \ldots & 27\end{array}$

A difference of one on either side of two main tentacles $\quad \ldots \quad 28$

A difference of two on either side of two main tentacles $\quad \ldots \quad 3$

A difference of three on either side of two main tentacles $\quad . . \quad 3$

Thus it appears that the normal increase of the number of tentaculae is by the addition of one tentacula at a time on either side of the medusa.

A. rugosum appears to be rather prone to abnormality. Of the two abnormal specimens mentioned in the above table, one had the following arrangement: one large tentacle with single radial canal, eight marginal tentaculae with no radial canal, one large tentacle with radial canal which bifurcated near its origin from the stomach with the two branches rejoining at the tentacle bulb, one marginal tentacula, one half-size large tentacle with a radial canal, eight tentaculae with the normal radial canal among them. In the other, one of the tentacular radial canals had bifurcated giving rise to a fully developed large tentacle at the end of each branch; its arrangement was one large tentacle, two tentaculae, one large tentacle, five tentaculae, one large tentacle, seven tentaculae. Other abnormal specimens were seen, one in which there was only one large tentacle, the place of the missing tentacle being taken by a tentacula; and two in which there were three large tentacles, in one of which the additional large tentacle was adradially situated and not opposite a radial canal.

Pochella polynema Hartlaub.

In May I934 a specimen of P. polynema ${ }^{\star}$ was taken off Plymouth. The medusa (Fig. $2 a$ ) was $2.7 \mathrm{~mm}$. in diameter; it had thirty tentacles, fifteen large and fifteen small, each springing from a brown marginal bulb. The four radial canals were not observed to be branched, and the preserved specimen is too contracted to show branches if they were present.

This species was described by Hartlaub (I9I7) from seventeen specimens collected from the northern North Sea in June 1905. It has never been recorded since from European waters.

In I936 while I was in Edinburgh Mr P. Gray showed me a number of slides of medusae that he had collected from the Firth of Clyde. Among these were two labelled Pochella? polynema. Mr Gray very kindly gave me one of these slides, a drawing of which is reproduced in Fig. $2 b$. This specimen, a female collected in Loch Fyne in April r934, has twenty-seven tentacles, sixteen of which are large and eleven smaller. It is $2.4 \mathrm{~mm}$. in height (mounted on slide). The ovaries are interadially situated on the stomach. The solid core of endoderm cells in the tentacles is to be clearly seen.

* Is this Oceania pusilla of Gosse, "Devonshire Coast", I853, p. 384, Pl. I3, figs. II-I4? 
There can be little doubt that these specimens are the same species as Hartlaub's medusae.

Hartlaub states that occasionally the radial canals were branched, the branches starting about at the middle of the canal and running outwards towards the umbrella edge; some were short and blind, and some longer. In the mounted specimen that I have there is definitely no branching of the radial canals. When, however, I showed these medusae to $\mathrm{Mr} \mathrm{E}$. T. Browne he turned up from his collection two specimens taken 40 years ago at Plymouth and labelled by him as a new species of Proboscidactyla. These specimens differ in no respect from mine except that very delicate branches

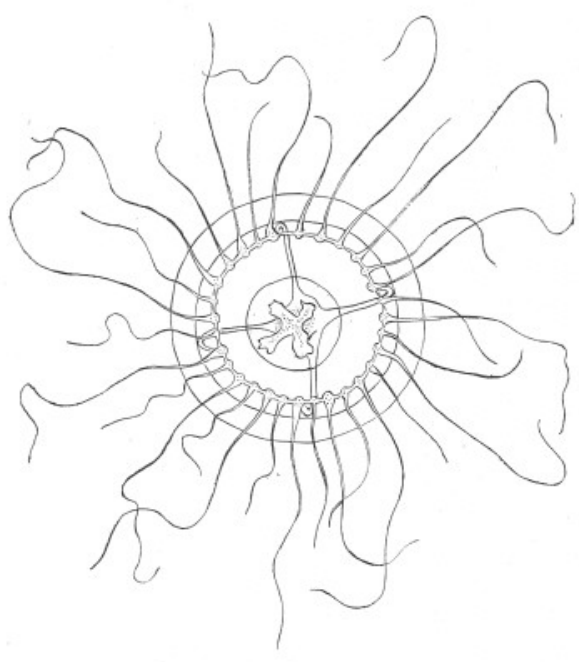

$a$

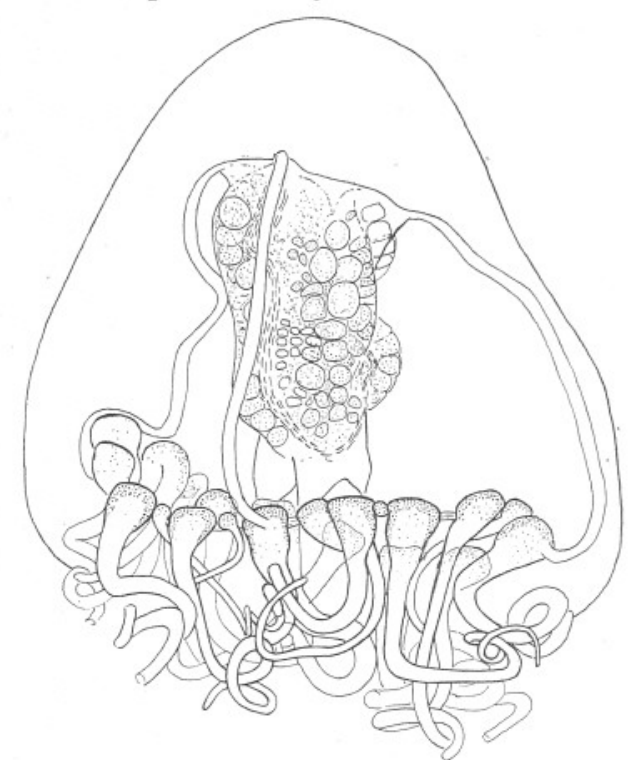

$b$

Fig. 2. Pochella polynema. a, living medusa $2.7 \mathrm{~mm}$. in diameter caught off Plymouth May 25 I934. $b$, mounted specimen collected by Mr P. Gray from Loch Fyne, April I 934.

can be seen on some of the radial canals, much as described by Hartlaub. The specimens are too contracted to allow detailed observation of the branching system.

One of the specimens, taken by $\mathrm{Mr}$ Browne on June $30 \mathrm{I} 898$, is $2.0 \mathrm{~mm}$. in height (preserved in formalin) and has thirty-two tentacles, larger and smaller ones approximately alternating. It is a mature male. The four gonads are situated on the interradii of the stomach (Fig. $3 a$ ). Two opposite gonads have the form of large cushions with their thickest parts at the upper ends. The other two gonads are thickest at their lower ends so that when viewed laterally they may be seen projecting as lobes on either side of the lower halves of the other two gonads (Fig. $3 b$ ). The other specimen, taken on May 26 I898, is $\mathrm{I} \cdot 4 \mathrm{~mm}$. in height (preserved in alcohol) and has thirty-three tentacles. 
In none of the above specimens was there any indication of exumbrella nematocyst canals, neither did Hartlaub find any. Until more specimens are obtained we cannot state whether the ring canals are solid. The systematic position of this species still remains problematical until more of its life history is known. There is, of course, the possibility that the medusae with unbranched radial canals may be different species from those in which the radial canals are branched. The fact that Hartlaub caught his seventeen specimens all together, some of which were with branched canals and others without, rather suggests, however, that they were all one species.

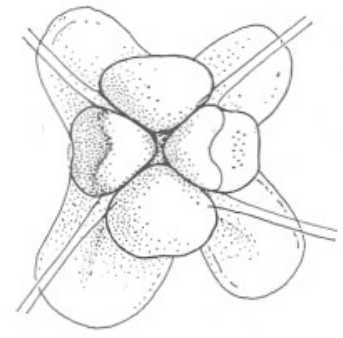

a

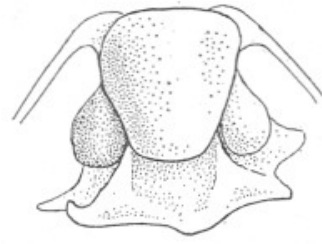

7.

Fig. 3. Pochella polynema, Plymouth, June 30 I898 (E. T. Browne's collection). $a$, aboral view of gonads; $b$, lateral view.

The species has been recorded from Departure Bay, on the Pacific coast of North America, by Foerster (1923, p. 30), who called it Proboscidactyla polynema. In his specimens there were fine thread-like branches from the radial canal "invisible except under the high power of the microscope". The medusae were $2-4 \mathrm{~mm}$. in diameter and there were $\mathrm{I} 2$ tentacles in each quadrant.

Foerster placed the species in the genus Proboscidactyla, but the gonads are not radial outgrowths from the stomach, neither are there exumbrella nemetocyst channels. On account of these differences it seems better to keep the genus Pochella distinct. In its affinities it is perhaps nearest to the Williidae, and if future research should show that it belongs to that family the characters of the family will have to be emended to take it.

\section{Laodicea undulata (Forbes \& Goodsir).}

The probability that $L$. undulata cannot be regarded as a truly indigenous species off Plymouth has already been mentioned (p. 4I5). Kramp (I930) concluded that the species was indigenous in the southern North Sea because it was abundant in I906, a year in which the influx of water from the Channel into the North Sea was only slight. It is, however, noteworthy that I 1906 was the year following two successive years, 1904 and 1905 , in which the influx was above the normal. It is thus possible that this may have been an instance of hydroids having developed on the sea bottom from mature medusae carried into the area in previous years. Kramp states that the medusae produced in 
the southern North Sea were considerably dwarfed, the majority being less than $8 \mathrm{~mm}$. in diameter. In 1937 none of the Laodicea seen off Plymouth exceeded $7 \mathrm{~mm}$. in diameter, and it appears that this is a parallel phenomenon with that observed by Kramp. It is probably an indication that the conditions of Channel water are not suitable for the successful growth of the medusa. In years when Laodicea occurs off Plymouth in large numbers the medusae are up to $15-20 \mathrm{~mm}$. in diameter.

Cosmetira pilosella Forbes.

Two species of Cosmetira are recorded from the north Atlantic, C. pilosella Forbes and C. megalotis (Maas). The usual distinctions given between these two species in recent literature are (see e.g. Hartlaub, I909, and Kramp, I933):

$\begin{array}{lll} & \text { C. pilosella } & \text { C. megalotis } \\ \text { Umbrella diameter } & \text { ca. } 20 \mathrm{~mm} . & 30-40 \mathrm{~mm} . \\ \text { Number of tentacles } & \text { ca. } 64 & \text { ca. } 100 \\ \text { Gonads/radial canal } & \frac{3}{4} & \frac{1}{3}-\frac{1}{2}\end{array}$

This appears to overlook Forbes' (I848) original description of C. pilosella in which he gives the number of tentacles as $(24 \times 4+4)$, i.e. 100, and whose figure of the medusa shows at least eighty-two tentacles.

\begin{tabular}{|c|c|c|c|c|c|c|c|c|c|c|c|}
\hline \multirow{3}{*}{$\begin{array}{c}\begin{array}{c}\text { Di- } \\
\text { ameter } \\
\text { mm. }\end{array} \\
\text { I5 }\end{array}$} & \multicolumn{9}{|c|}{ Tentacles and Developing Bulbs } & \multirow{3}{*}{$\begin{array}{c}\begin{array}{c}\text { Length } \\
\text { of } \\
\text { gonad } \\
\text { mm. }\end{array} \\
6\end{array}$} & \multirow{3}{*}{$\begin{array}{l}\text { Sex } \\
\qquad \text { 우 }\end{array}$} \\
\hline & \multicolumn{8}{|c|}{ Numbers between every two marginal vesicles } & \multirow{2}{*}{$\frac{\text { Total }}{68}$} & & \\
\hline & 8 & 8 & 9 & 7 & 8 & 8 & $\mathrm{I} 2$ & 8 & & & \\
\hline & II & 7 & 9 & 6 & II & 6 & II & 6 & 67 & 4 & \\
\hline 16 & II & 6 & Io & 6 & IO & 9 & II & 8 & $7 \mathrm{I}$ & 4 & $\hat{\sigma}$ \\
\hline I6 & I3 & I0 & 12 & II & II & 9 & $\mathrm{I} 2$ & IO & 88 & $6 \cdot 5$ & oै \\
\hline I6 & 13 & II & I2 & 9 & I3 & 9 & II & I I & 89 & $\ldots$ & . \\
\hline I7 & 12 & 9 & I3 & II & $25^{\star}$ & $20^{\star}$ & & & 90 & 5 & \\
\hline I7 & Io & II & 7 & II : & $: 7$ & II & 8 & $8: \mathrm{I} \dagger$ & 76 & 5 & ô \\
\hline 17 & IO & 9 & 12 & 9 & II & $15^{\star}$ & 8 & & 74 & 5 & 0 \\
\hline 18 & I2 & 13 & I0 & 12 & 10 & II & II & I3 & 92 & 7 & 0 \\
\hline I8 & II & 12 & I3 & I4 & 8 & I5 & 7 & 12 & 92 & 7 & o \\
\hline 18 & I0 & 8 & 12 & 9 & 9 & 8 & II & 9 & 76 & 5.5 & $\hat{0}$ \\
\hline I8 & IO & 8 & 9 & 7 & 13 & II & II & 8 & 77 & 6 & ô \\
\hline 18 & II & 8 & 12 & 8 & 13 & 9 & 12 & 8 & 81 & $5 \cdot 5$ & $\hat{\sigma}$ \\
\hline I8 & II & II & 12 & $2 I^{\star}$ & I0 & II & 8 & & & 6.5 & \$ \\
\hline 19 & I0 & IO & I2 & II & 16 & IO & $\mathrm{I} 4$ & I0 & 93 & Short & $\hat{\sigma}$ \\
\hline 19 & II & 7 & 7 & 9 & I2 & 8 & II & 7 & 72 & 5 & $\hat{o}$ \\
\hline 19 & 13 & 12 & 12 & II & 13 & II & I6 & II & 99 & 7 & $\hat{o}$ \\
\hline 19 & I3 & 9 & IO & 9 & 10 & 9 & $\mathrm{I} 2$ & 9 & $8 \mathrm{I}$ & $6 \cdot 5$ & ơ \\
\hline 20 & II & 9 & II & II & II & 8 & IO & 9 & 80 & $5 \cdot 5$ & T \\
\hline 20 & I2 & 7 & I2 & 7 & I3 & 8 & 9 & & 68 & & $\ddot{0}$ \\
\hline $2 \mathrm{I}$ & I2 & 9 & I3 & 9 & I 2 & 8 & II & 8 & 82 & 6.5 & के \\
\hline $2 \mathrm{I}$ & I5 & 3 & I5 & II & II & 9 & II & IO & 85 & $8 \cdot 5$ & † \\
\hline 22 & I3 & 7 & IO & 4 & I0 & 8 & IO & 6 & 68 & $4 \cdot 5$ & \\
\hline 22 & II & II & II & I0 & 9 & 8 & 8 & 9 & 77 & 7 & $\hat{0}$ \\
\hline 22 & I3 & II & I2 & 9 & I2 & 8 & $\mathrm{I} 2$ & 8 & 85 & 6 & 0 \\
\hline 23 & II & I0 & 8 & 12 & II & 9 & II & 9 & $8 \mathrm{I}$ & .. & .. \\
\hline 23 & II & 9 & II & IO & I2 & 9 & II & 9 & 82 & 7 & 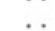 \\
\hline 24 & IO & 8 & 12 & 8 & I4 & 9 & $19^{\star}$ & & 80 & 7 & 우 \\
\hline 24 & II & 9 & I3 & 9 & 12 & I0 & II & I2 & 87 & 8 & 0 \\
\hline 26 & Io & 9 & 14 & 9 & $20^{\star}$ & Io & 7 & & 79 & 8 & ot \\
\hline
\end{tabular}


On August I7 I932 a number of $C$. pilosella caught off Plymouth were preserved for careful examination. The results are shown in the above table, in which are given the diameter of the medusa, the numbers of tentacles and developing bulbs between every two marginal vesicles beginning with a radial canal octant, the total number of tentacles and bulbs, and the lengths of the gonads.

This table shows that the diameters of the medusae varied between 15 and $26 \mathrm{~mm}$., and that the numbers of tentacles and bulbs ranged from sixty-seven to ninety-nine. The length of the gonads varied from 0.2 to 0.4 of the diameter of the umbrella, or taking the radial canal length as approximately half that of the umbrella $c a .0 \cdot 4-0.8$ of the radial canal, or slightly less allowing for the width of the stomach. It is probable that in the preservation some medusae have contracted more than others.

Thus the number of tentacles and size of the gonads of $C$. pilosella at Plymouth overlap those given for $C$. megalotis, and the only remaining difference between the two species is in the size of the umbrella. Incidentally in this respect the Misses Delap (I905) record specimens from Valencia up to $48 \mathrm{~mm}$. in diameter which were fully mature.

Künne (1937), using Cosmetira as an indicator of northern water in the southern North Sea, decided that his specimens were C. megalotis. While cruising in Col. Peel's yacht St George in I933 I obtained some specimens of Cosmetira from north of the Fair Isle Channel (July 9 I933; $59^{\circ} 42^{\prime} \mathrm{N}$, $2^{\circ} \mathrm{IO}^{\prime} \mathrm{W}$.). The diameters, numbers of tentacles and bulbs, and length of gonads (when not lost) were as follows:

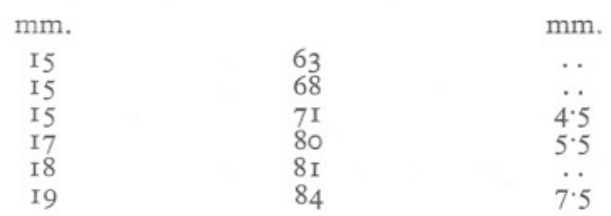

These figures agree closely with those for the Plymouth medusae, and there can be no doubt that they were $C$. pilosella.

Tiaropsis multicirrata (M. Sars).

This species has only once been recorded at Plymouth: by Dr E. J. Allen in April I895. On April 2I I934 a very small specimen was taken in the Sound. This was $\mathrm{I} \cdot 39 \mathrm{~mm}$. high and $\mathrm{I} \cdot 25 \mathrm{~mm}$. wide and had about twentyfour tentacles. The presence of so small a specimen must have been an indication that the hydroid was living in the locality. Its hydroid is unknown, but the extreme rarity of the medusa shows that it cannot normally be indigenous off Plymouth.

Phialidium hemisphericum (L.).

Phialidium is, with Obelia spp., by far the commonest species of medusa off Plymouth, and it may be taken in any month of the year. There is, however, 
a great decrease in numbers in the winter months, and it may sometimes be entirely absent in January and February. Observations by Orton (I920) showed that its hydroid, Clytia johnstoni, liberates medusae from March to October, and I have seen them liberated in November.

Two rather different forms are found in the plankton: a large form with elongated gonads, especially in the spring and early summer, and a small form with short oval gonads in the autumn. This has in the past given rise to the

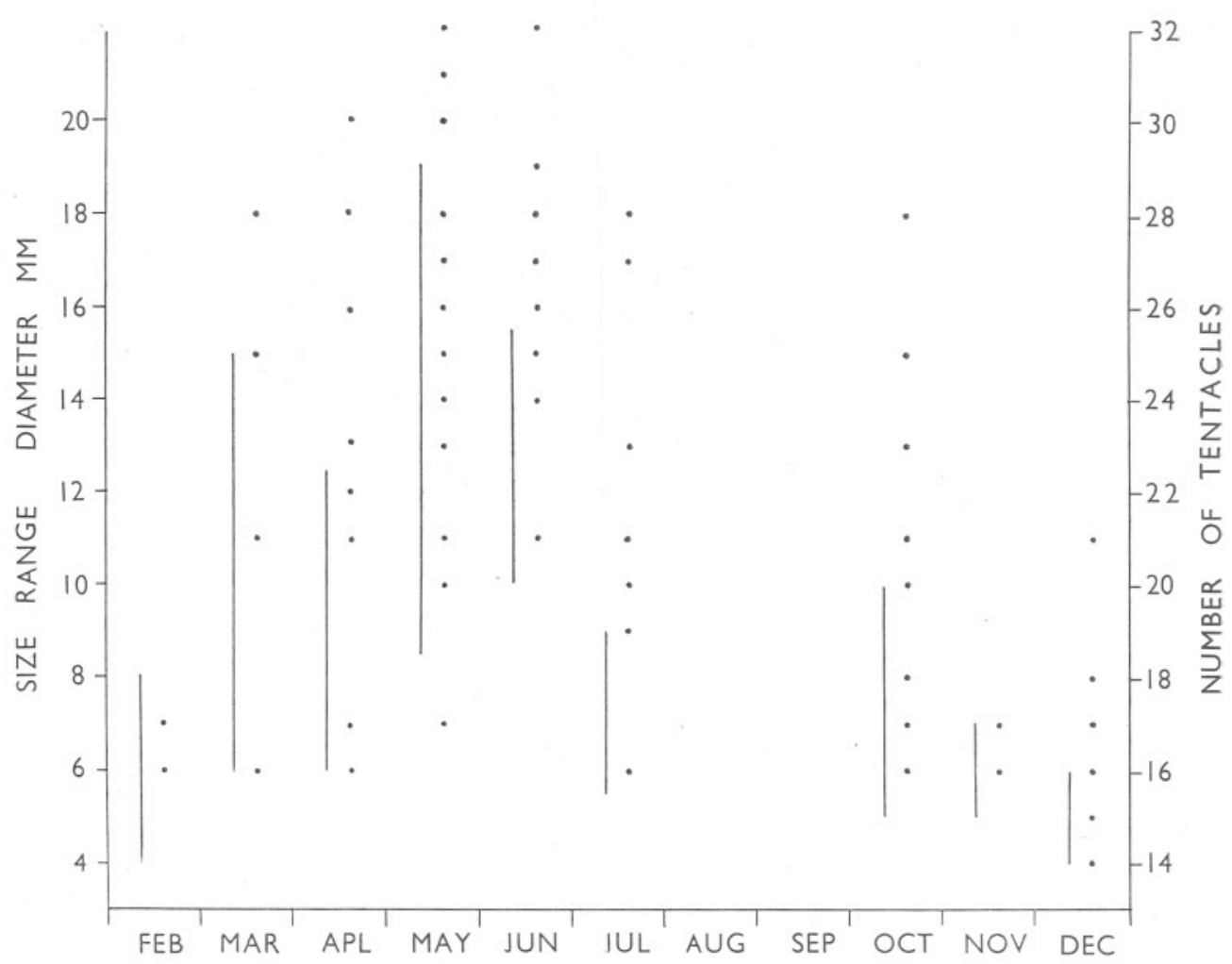

Fig. 4. Seasonal variation in diameter and number of tentacles of Phialidium hemisphericum in the plankton off Plymouth I933 and 1934. The continuous lines show the size range and the dots the range of tentacle numbers.

idea that there may be two species (see Browne, I896, p. 489), but it is now generally agreed that there is only one. The difference is due to seasonal variation in size and the following observations confirm this.

During 1933 and 1934 a large number of living Phialidium were measured and their tentacles counted. The results are given in Fig. 4, which shows the size range for mature medusae in each month of the year (except August and September) and the numbers of tentacles (including developing bulbs) that they had. It shows clearly that in the spring and early summer the 
medusae grow to a larger size than at other times of the year. The maximum size reached was $19 \mathrm{~mm}$. diameter in May. Also, as might be expected, the largest medusae have the greatest number of tentacles. These reached a maximum of thirty-two in May and June, while by October they were usually sixteen to eighteen fully formed tentacles, any larger numbers being made up with developing bulbs.

Browne (I900) found that at Valencia the largest specimen taken, in May, was $20 \mathrm{~mm}$. in width and had thirty-eight tentacles, the average size of the adult being IO-I $5 \mathrm{~mm}$. with about thirty-two tentacles. Similarly at Port Erin (I896, p. 490) he found the largest specimen to be $2 \mathrm{I} \mathrm{mm}$. and to have thirty-eight tentacles.

As observed by Browne I have occasionally seen specimens at Plymouth having one or two marginal vesicles containing two concretions. The largest number of marginal vesicles seen in any one specimen at Plymouth was eighty-nine (two of which each had two concretions); this was in a specimen I9 mm. in diameter taken on May I5 I934, which had thirty-two tentacles.

Measurements made on the gonads of medusae of different sizes gave the following results:

\begin{tabular}{|c|c|c|c|c|}
\hline \multirow{2}{*}{$\begin{array}{l}\text { Umbrella } \\
\text { diameter } \\
\text { mm. }\end{array}$} & \multicolumn{3}{|c|}{ Gonad length (mm.) } & \multirow{2}{*}{$\begin{array}{c}\text { Ratio diameter* : } \\
\text { av. gonad } \\
\text { length }\end{array}$} \\
\hline & Average & Range & Observations & \\
\hline $4 \cdot I-5$ & 0.30 & $0.21-0.76$ & II & $15 \cdot 0$ \\
\hline $5 \cdot I-6$ & 0.59 & $0.4-0.75$ & I5 & $9 \cdot 3$ \\
\hline $6 \cdot I-7$ & 0.67 & $0 \cdot 3-I \cdot I$ & 17 & $9 \cdot 9$ \\
\hline $7 \cdot I-8$ & 0.98 & $0.75-I \cdot 5$ & 6 & $7 \cdot 7$ \\
\hline $8 \cdot I-9$ & 0.94 & $0.5-I .5$ & 8 & 9.0 \\
\hline 9.I-IO & $I \cdot 26$ & $0.5-3.0$ & I3 & $7 \cdot 5$ \\
\hline IO.I-II & $\mathrm{I} \cdot 25$ & $0.75-2.0$ & 8 & $8 \cdot 4$ \\
\hline $\mathrm{II} \cdot \mathrm{I}-\mathrm{I} 2$ & $I \cdot 43$ & $I \cdot O-2 \cdot O$ & I4 & $8 \cdot 0$ \\
\hline $\mathrm{I} 2 \cdot \mathrm{I}-\mathrm{I} 3$ & $I \cdot 64$ & $\mathrm{I} \cdot \mathrm{O}-3 . \mathrm{O}$ & I3 & $7 \cdot 6$ \\
\hline $\mathrm{I}_{4} \cdot \mathrm{I}-\mathrm{I} 5$ & $\mathrm{I} \cdot 75$ & $I \cdot 5-2 \cdot 0$ & 2 & $8 \cdot 3$ \\
\hline $15 \cdot I-16$ & $2 \cdot \mathrm{I}$ & $I \cdot 5-3 \cdot 0$ & 7 & $7 \cdot 4$ \\
\hline $16 \cdot \mathrm{I}-\mathrm{I} 7$ & $2 \cdot 25$ & $2 \cdot 0-2 \cdot 5$ & 2 & $7 \cdot 3$ \\
\hline I8 & $3 \cdot 0^{\circ}$ & & I & $5 \cdot 8$ \\
\hline I9 & 3.5 & & I & $5 \cdot 4$ \\
\hline
\end{tabular}

Except for the smallest and the largest individuals the ratio of the average gonad length to the umbrella diameter thus appears to be fairly constant with a slight tendency to decrease with size. The figures for the smallest specimens are probably vitiated by the inclusion of immature specimens, while those for the two largest sizes are each based on a single observation.

The above observations on size of medusa, number of tentacles and gonad length, are somewhat different from those given by Kramp (I927) for Danish waters. There, while the smaller specimens $(6-7 \mathrm{~mm}$. diameter) occurred in summer, the larger specimens (II-I $2 \mathrm{~mm}$. diameter) were found in winter, though they reached $\mathrm{I} 6 \mathrm{~mm}$. in spring. While in July the number of tentacles rarely exceeded sixteen, in November they were as a rule twenty-four to 
twenty-eight. Kramp also says that the gonads are about one-quarter the length of the radial canals. This agrees approximately with the results for Plymouth, where the gonad length averages about one-eighth of the diameter of the umbrella of which a radial canal occupies approximately one half.

Kramp (1927) pointed out that the ratio of the width to the length of the gonads varied at different times of the year. Assuming that there is no very great difference in the size of the eggs at different times of the year it seems natural to expect the smaller gonads to be wider in relation to their length than the longer gonads.

The trend of the seasonal change in size at Plymouth is quite what is to be expected from observations on other plankton animals such as Calanus, Sagitta and Aglantha. It is shown by Phialidium, since this is one of the few medusae apart from Obelia which is consistently liberated from its hydroid into the plankton almost all the year through. It seems probable that Obelia should also show similar seasonal variation but this cannot be proved owing to the difficulty of identifying the species.

\section{Eucheilota clausa (Hincks).}

The existence of this species at Plymouth has only recently been brought to notice (Russell, $1936 b, c$ ). Other records of its seasonal occurrence have since been obtained and these have been incorporated in Table I. As the distribution of the species is not known the following information is worthy of note. In September 1936 I received a letter from Mr J. S. Barlee saying that he had caught a specimen I mm. in diameter at Valencia. On September Io he obtained two specimens, I and $4 \mathrm{~mm}$. in diameter respectively, in Dalkey Sound, Co. Dublin, and on September I5 a dozen larger specimens off Sandycove, near Kingstown, Co. Dublin. Mr Barlee kindly sent me the specimens, which were $E$. clausa. Later he sent me another specimen from Kingstown which was more fully developed than any so far recorded. It had fifteen fully developed tentacular bulbs and seven smaller ones and its gonads were $\mathrm{I} \cdot 2 \mathrm{~mm}$. long and $0.65 \mathrm{~mm}$. wide.

\section{Helgicirrha schulzei Hartlaub.}

In 1934 Künne drew attention to the distinction between Eirene viridula ${ }^{\star}$ and Hartlaub's species Helgicirrha schulzei, which had been rather overlooked. Careful examination revealed the fact that Helgicirrha occurs off Plymouth. I had not realized the existence of this species until I saw Künne's paper, and my records for the species only date from 1935. A few specimens were found in each of the years 1935-7, and they occur in the plankton in the months of June to October inclusive. Its seasonal distribution thus overlaps that of Eirene, which reaches its maximum abundance in September and October, and the two species are likely to be found together. A re-examination of samples

\footnotetext{
* No attempt has been made in this report to distinguish $E$. viridula and $E$. pellucida on the preserved material; they are possibly the same species.
} 
for the years previous to 1935 showed that the great majority of the specimens identified as E. viridula were correct. An occasional specimen of Helgicirrha was, however, found, but it is quite certain that they were too few to affect the general picture of the seasonal distribution of Eirene given in Table III.

In living specimens of Helgicirrha schulzei there are fine specks of deep indigo pigment all round the extreme margin of the umbrella. This pigment was not present in living specimens of Eirene pellucida.

The genera Eirene and Helgicirrha have recently been revised by Kramp (I936). He pointed out that Hartlaub's spelling schulzii should be more correctly schulzei.

Aglantha rosea (Forbes).

In I930 Aglantha, which always accompanies "elegans" water, was present off Plymouth throughout most of the year. The opportunity was taken to see whether size measurements would throw any light on the life history of this medusa. The umbrella height was accordingly measured on samples from each catch. In Fig. 5 a curve is given showing the actual numbers caught between February and October. The numbers were low until June when they began to increase very rapidly, reaching a maximum of many thousands in August. Curves are also given in Fig. 5 for the height measurements of the medusae on each date. From February to April the Aglantha were large, being $\mathrm{I} 2-\mathrm{I} 8 \mathrm{~mm}$. in height. A new brood, presumably arising from these large individuals, appeared in April, and these medusae reached a size of 6-8 mm. in May. Thereafter reproduction was rapid and the production of successive generations probably overlaps. Nevertheless, the height measurements do appear to give some indication of successive generations. In Fig. 5 a large dot is placed on the base line opposite the highest peak for each curve. It can be seen that there are three definite series in June, July and August each one of which starts at a small size and shows a gradual increase to a maximum. Perhaps too much stress should not be laid on these until they can be repeated in another year, but the indications are that three successive generations arose in June, July and August, each taking about I month to grow up. In September there was a slight increase in the size of the medusae, and it is probable that these live through the winter to grow into the large individuals found in February.

The annual sequence thus seems to be as follows: The year starts with large individuals $\mathrm{I} 2-\mathrm{I} 8 \mathrm{~mm}$. in height which were produced by the last spawning of the previous year. These large medusae spawn in late March and their offspring mature in May, after which there are three, or possibly four, successive generations produced in the summer. These summer medusae only grow to a height of about $5-7 \mathrm{~mm}$. Five or six generations are thus produced in a year.

The large individuals found from February to April were strong and muscular, a characteristic of deep water medusae. Kramp (I927) records 


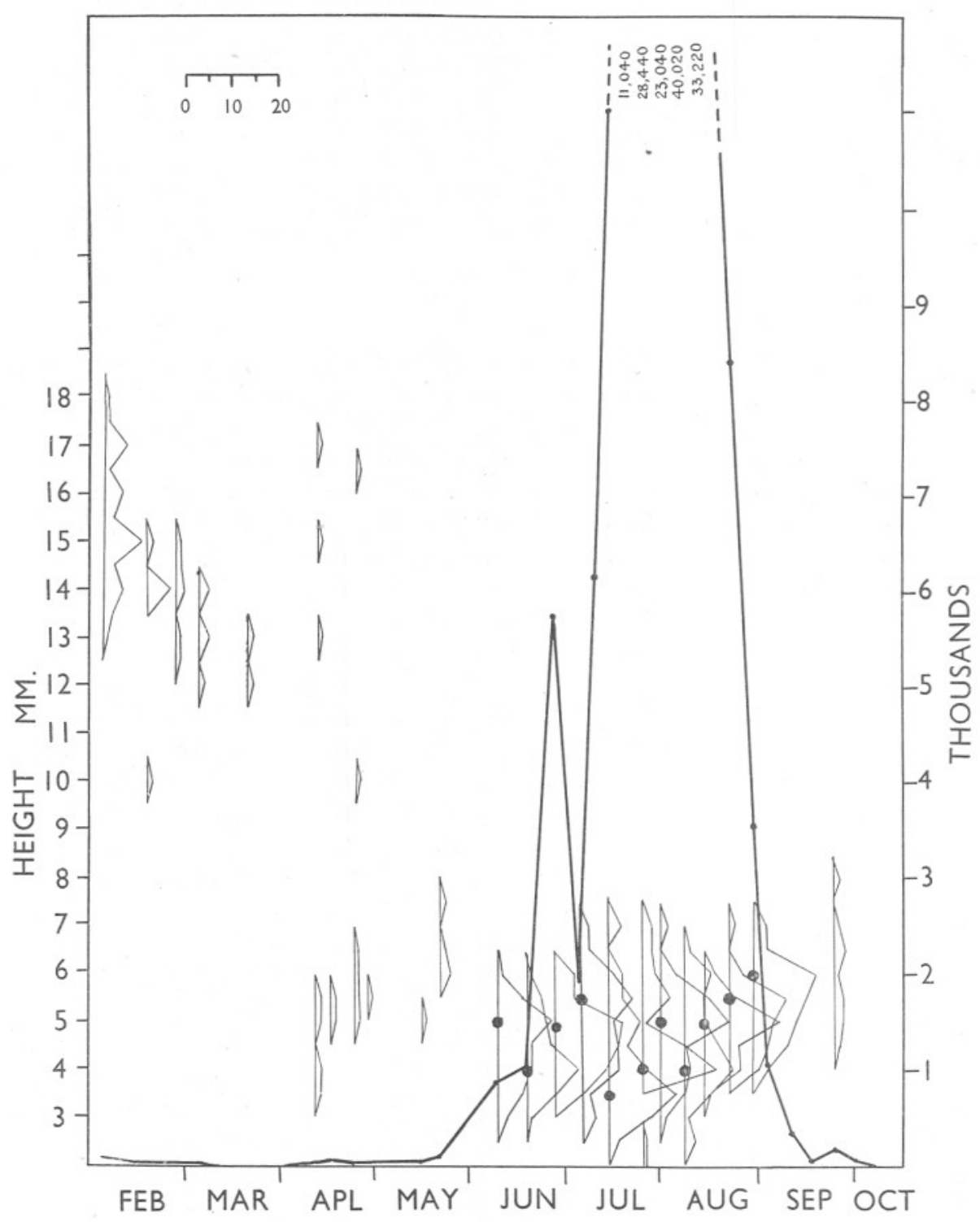

Fig. 5. Numbers and size of Aglantha rosea in half-hour oblique hauls with the $2 \mathrm{~m}$. stramin ringtrawl off Plymouth in I930. The thick curve gives the numbers caught in thousands; the small curves show the size distribution in each catch, the scale for numbers being in the top left-hand corner. 
that two forms are to be found in Danish waters, one inhabiting the North Sea and upper water layers of the Skagerrak reaching a height of $16 \mathrm{~mm}$. and a smaller form found in the Kattegat and Belt Sea hardly growing to more than $\mathrm{I} 2 \mathrm{~mm}$. in height. He makes the suggestion that it is the shallowness of the water that renders the Belt Sea unsuitable as a permanent habitat for Aglantha. It may well be that the large medusae found off Plymouth had come from deep water where they need to retire for the winter months, and that this necessity prevents them from becoming permanently established in the waters off Plymouth. Günther (I903) says concerning A. rosea off the west of Ireland: "It seems possible that fully developed Aglantha may live near the surface during the summer months, but may sink into deeper waters with the advancing season."

It is uncertain whether $A$. rosea should be regarded as a variety of $A$. digitalis or as a distinct species. The chief structural difference, apart from size, is that while in $A$. digitalis there are only four marginal sense organs, in $A$. rosea there are eight. In March I936 I obtained some very young specimens of $A$. rosea off Plymouth and was able to examine them alive. Specimens up to just under $4 \mathrm{~mm}$. in height, with twenty to thirty tentacles, had only four sense organs; a specimen $4.4 \mathrm{~mm}$. in height with thirty-four tentacles had five sense organs, while specimens 5 and $6 \mathrm{~mm}$. in height had eight. It is evident that the number of marginal sense organs increases from four to eight when the medusa is somewhere between 4 and $5 \mathrm{~mm}$. high. Since $A$. rosea begins by developing four sense organs and not eight it is unnecessary to suppose that, if it is a variety, $A$. digitalis must have lost four sense organs during the course of its development. It must remain therefore a matter of opinion whether the two are to be regarded as varieties or distinct species on account of their different distribution and habits.

\section{SUMMARY}

The composition of the medusa fauna in offshore waters off Plymouth is reviewed. A table is given showing the months in which the different species have been recorded and those months in which they are most abundant.

A preliminary list has been drawn up attempting to discriminate between those species which are regularly indigenous off Plymouth and those which are brought from elsewhere by water movements.

The results of weekly hauls with the $2 \mathrm{~m}$. stramin ringtrawl during the years $1930-7$ inclusive are given. The years I935, I936 and I937 have been noteworthy for the paucity of all species of medusae.

Observations on the structure and biology of certain species of medusae are recorded. 


\section{Table III. Average Catches for each Month in the Years I930-7}

Half-hour oblique hauls with $2 \mathrm{~m}$. stramin ringtrawl

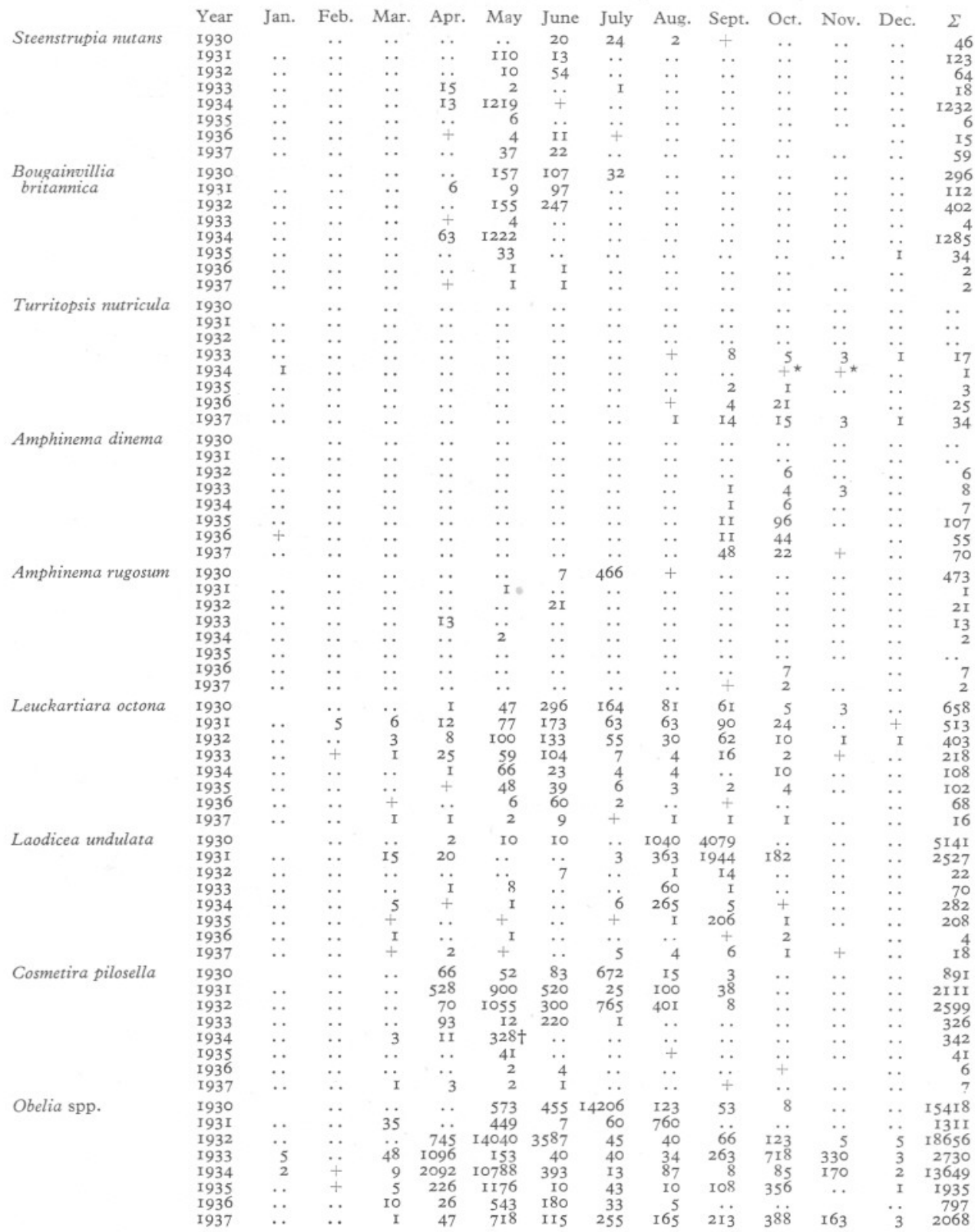

* Seen in townet catches.

† I had in my notes a record for May 29 "many". I have given this number as I000. 
TABLE III (cont.)

Half-hour oblique hauls with $2 \mathrm{~m}$. stramin ringtrawl.

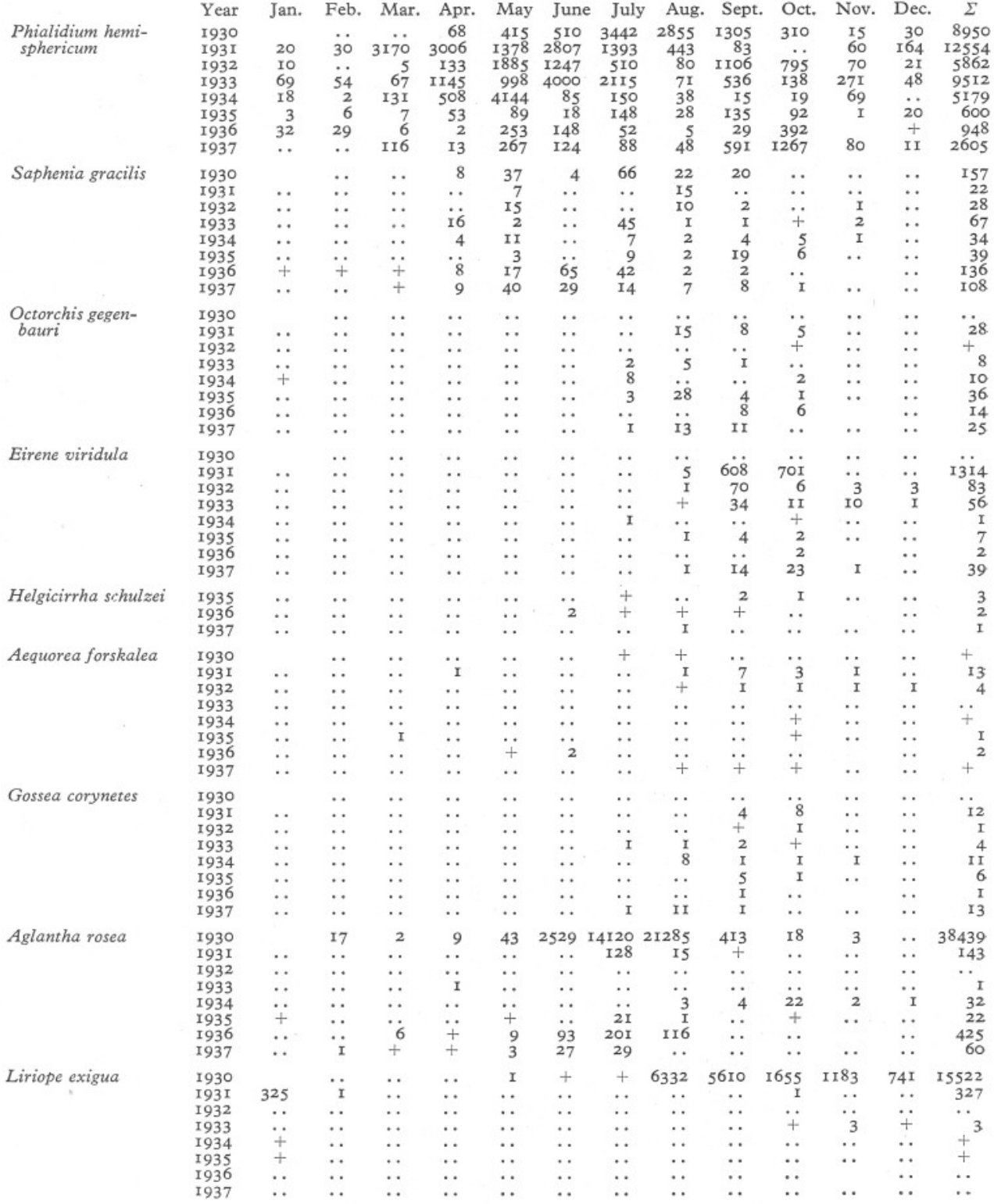




\section{REFERENCES}

Bigelow, Henry B., I9I3. Medusae and Siphonophorae collected by the U.S. Fisheries Steamer "Albatross" in the Northwestern Pacific, 1906. Proc. U.S. Nat. Mus., Vol. 44, No. 1946, pp. I-I I9.

Browne, Edward T., 1896. On British Hydroids and Medusae. Proc. Zool. Soc. London, pp. 459-500.

- r898. On the pelagic fauna of Plymouth for September, 1897. Fourn. Mar. Biol. Assoc., Vol. v, pp. I86-92.

- 1900. The fauna and flora of Valencia Harbour on the west coast of Ireland. II. The Medusae (1895-98). Proc. Roy. Irish Acad., 3rd Ser., Vol. v, No. 5, pp. $694-736$.

- 1902. A Preliminary Report on Hydromedusae from the Falkland Islands. Ann. Mag. Nat. Hist., Ser. 7, Vol. Ix, pp. 272-84.

- 1906. Biscayan plankton collected during a cruise of H.M.S. "Research", I900. Part IX. The Medusae. Trans. Linn. Soc. (Zool.) London, 2nd ser. Vol. x, Pt 6, pp. $163-87$.

- I910. Coelentera. V. Medusae. National Antarct. Exped. I90 I-I904, Nat. Hist., Vol. v, Zool. and Bot., pp. I-62.

Carruthers, J. N., I934. The flow of water past the Seven Stones Lightvessel. Fourn. Mar. Biol. Assoc., Vol. xIx, pp. 92 I-30.

Delap, M. and C., I905. Notes on the plankton of Valencia Harbour, I899-I90I. Ann. Rep. Fish. Ireland, I902-03, Pt. II, App. I [1905], pp. I-I9.

- 1906. Notes on the plankton of Valencia Harbour. Fisheries, Ireland, Sci. Invest., r905, No. vil, pp. 3-2I.

Foerster, R. EARLE, I923. The Hydromedusae of the west coast of North America, with special reference to those of the Vancouver Island Region. Contr. Canad. Biol. N.S., Vol. I, No. I2, pp. 22 I-77.

Forbes, EDWARD, I848. A Monograph of the British Naked-eyed Medusae. Ray Society.

Garstang, Walter, I894. Faunistic notes at Plymouth during 1893-4. Fourn. Mar. Biol. Assoc., Vol. III, pp. 210-35.

GÜNTHER, R. T. I903. Report on the Coelenterata from the intermediate waters of the N. Atlantic, obtained by Mr George Murray during the Cruise of the "Oceana" in I898. Ann. Mag. Nat. Hist., Ser. 7, Vol. XI, pp. 420-30.

Hartlaub, C., I909. Über Thaumantias pilosella Forbes und die neue LafoëidenGattung Cosmetira. Zool. Anz., Bd. xxxiv, Nr. 3/4, I. Wiss. Mitt. 2, pp. 82-9.

- I9r r. Craspedote Medusen, Teil I, Lief. 2, Margelidae. Nordisches Plankton, Lief. I5, XII, pp. I37-235.

- I917. Craspedote Medusen. Teil I, Lief. 4. Nordisches Plankton, Lief. I9, XII, pp. $365-479$.

Kramp, P. L., I927. The Hydromedusae of the Danish Waters. D. Kgl. Danske Vidensk. Selsk. Skr., Naturvid. Math., Afd. 8, Raekke XII, No. I, pp. I-29I.

- 1930. Hydromedusae collected in the south-western part of the North Sea and in the eastern part of the Channel in 1903-1914. Mém. Mus. Roy. Hist. Nat. Belgique, Mem. No. 45, pp. I-55.

- I933. Craspedote Medusen. Teil 3, Leptomedusen. Nordisches Plankton, Lief. 22, XII, pp. 54I-602.

- 1936. On the Leptomedusae of the Genera Eirene Eschscholtz and Helgicirrha Hartlaub. Vidensk. Medd. Dansk. Naturh. Foren., Bd. 99, pp. 239-62.

KüNNE, CL., 1934. Über die Leptomedusen Helgicirrha schulzii Hartlaub und Eirene viridula (Péron und Lesueur). Zool. Anz., Bd. I06, Heft I/2, pp. 27-34. 
KüNNE, Cl., I937. Über die Verbreitung der Leitformen des Grossplanktons in der südlichen Nordsee im Winter. Ber. Deutsche Wiss. Komm. Meeresforsch., Berlin, N.F., Bd. viII, Heft 3, pp. I3I-64.

Mayer, Alfred Goldsborough, I9io. Medusae of the World, Vol. I, pp. I-230.

ORTON, J. H., I920. Sea-temperature, breeding and distribution in marine animals. Fourn. Mar. Biol. Assoc., Vol. xII, pp. 339-66.

REES, W. J. \& RuSSELL, F. S., I937. On rearing the hydroids of certain medusae, with an account of the methods used. Fourn. Mar. Biol. Assoc., Vol. xxII, pp. 6I-82.

RUSSELL, F. S., I933. The seasonal distribution of macroplankton as shown by catches in the 2-metre stramin ring-trawl in offshore waters off Plymouth. Fourn. Mar. Biol. Assoc., Vol. xIx, pp. 73-82.

- 1930-8. The seasonal abundance and distribution of the pelagic young of Teleostean fishes caught in the ring-trawl in offshore waters in the Plymouth area. I-V. Fourn. Mar. Biol. Assoc., Vols. XVI, p. 707; xx, pp. I47 and 595; XxI, p. 679 ; XXII, pp. 493-500.

- I936 a. The importance of certain plankton animals as indicators of water movements in the western end of the English Channel. Rapp. Proc. Verb. Int. Cons. Explor. Mer, Vol. c, pp. 7-Io.

- I936 b. On a new species of medusa, Eucheilota hartlaubi n.sp. Fourn. Mar. Biol. Assoc., Vol. xx, pp. 589-94.

- I936 c. On the first stage of the medusa Eucheilota clausa (Hincks) [=E. hartlaubi Russell]. Fourn. Mar. Biol. Assoc., Vol. xxI, pp. I3I-3.

Russell, F. S., \& ReES, W. J., I936. On rearing the hydroid Zanclea implexa (Alder) and its medusa Zanclea gemmosa McCrady, with a review of the genus Zanclea. Fourn. Mar. Biol. Assoc., Vol. xxi, pp. 107-130.

Thiel, MAX Egon, I932. Die Hydromedusen-fauna des Nördlichen Eismeeres in tiergeographischer Betrachtung. Arch. Naturgesch. Berlin, Abt. B, N.F., Bd. I, Heft 3, pp. 435-5I4.

WulfF, A., BüCKMANN, A., \& KüNNE, Cl., I934. Bericht über die Teilnahme an einer Fischereischutzfahrt der "Weser" zu Untersuchungen über die Verbreitung der Heringslarven in der Südlichen Nordsee und dem Kanaleingang. 7 November bis I5 December 1933. Ber. Deutsche Wiss. Komm. Meeresforch., Berlin, N.F., Bd. vII, Heft 3, pp. 328-42. 